\title{
TINJAUAN YURIDIS MEKANISME PENDAFTARAN CALON PERSEORANGAN DAN PARPOL DALAM PILWALI DI KOTA KEDIRI
}

\author{
Agus Manfaluthi \\ Fakultas Hukum Universitas Islam Kadiri (UNISKA) \\ Jalan Sersan Suharmaji No.38 Kediri, Jawa Timur, Indonesia
}

\begin{abstract}
Objective research titled Judicial Review of Registration Mechanism for Independent Candidates and Political Parties in the General Election of Mayor and Deputy Mayor (Pilwali) in 2013 to determine the depth of the registration mechanism for independent candidates and political parties in the general election of Mayor and Deputy Mayor in Kediri. The question is whether Kediri has been carrying out the registration procedure in accordance with the rules applicable. To mind the new independent candidates Pilwali adopted in 2013 in Kediri where it is the first time to implement Election Mayor followed by independent candidates. This research is conducted using empirical methods to the scope of research locations in the Election Commission office Kediri. The result: Based on Law Number 12 Year 2008 began chapters 58 to 60, the General Election Commission (KPU), Kediri City has been implementing a mechanism for registration of candidates for Mayor and Deputy Mayor came from political parties, the combined political parties and candidates Individual earnest, result all independent either from independent or from political party and coalition of political parties passed the registration stage.
\end{abstract}

Keywords: Judicial Review, Registration Mechanism, Political Parties.

\begin{abstract}
ABSTRAK
Tujuan penelitian dengan judul Tinjauan Yuridis Mekanisme Pendaftaran Calon Perseorangan dan Partai Politik dalam Pemilihan Umum Walikota dan Wakil Walikota (Pilwali) Tahun 2013, untuk mengetahui secara mendalam tentang mekanisme pendaftaran calon perseorangan dan Partai Politik dalam pemilihan umum Walikota dan Wakil Walikota di Kediri. Persoalannya adalah apakah di Kota Kediri sudah melaksanakan prosedur pendaftaran sesuai dengan peraturan yanng berlaku. Mengingat calon perseorangan baru diadopsi dalam Pilwali tahun 2013 dan di Kota Kediri baru pertama kali melaksanakan Pemilihan Umum Walikota yang diikuti oleh calon perseorangan. Penelitin ini menggunakan metode empiris dengan ruang lingkup lokasi penelitian di kantor Komisi Pemilihan Umum Kota Kediri. Hasilnya: Berdasarkan Undang-Undang Nomor: 12 Tahun 2008 mulai pasal 58 hingga 60, Komisi Pemilihan Umum (KPU), Kota Kediri telah melaksanakan mekanisme pendaftaran calon Walikota dan Wakil Walikota berasal dari Parpol, gabungan Parpol dan calon Perseorangan dengan sungguh-sungguh hasilnya semua calon baik perseorangn maupun dari partai politik dan gabungan partai politik lolos dalam tahapan pendaftaran.
\end{abstract}

Kata Kunci : Tinjauan Yuridis, Mekanisme Pendaftaran, Partai Politik 


\section{A. PENDAHULUAN}

\section{Latar Belakang Masalah}

Kualitas kompetisi dalam pilkada sesungguhnya dapat dilihat dari sistem pencalonan atau pendaftaran calon yang digunakan. Pencalonan juga merupakan suatu dimensi hak pilih aktif, yakni hak warga untuk dipilih. Dimensi lainnya adalah hak warga untuk memilih. Karena itulah, pencalonan merupakan tahapan penting yang ditunggu-tunggu masyarakat, khususnya para politisi dalam pilkada langsung.

Berdasarkan Pasal 56 ayat (1) Undang-Undang Nomor 12 Tahun 2008 yang berbunyi Kepala daerah dan wakil kepala daerah dipilihdalam satu pasangan calon yang dilaksanakan secara demokratis berdasarkan asas langsung, umum, bebas, rahasia, jujur, dan adil.

Selanjutnya dalam Pasal 2 juga disebutkan bahwa pasangan calon sebagaimana dimaksud pada ayat (1) diusulkan oleh partai politik, gabungan partai politik, atau perseorangan yang didukung oleh sejumlah orang yang memenuhi persyaratan sebagaimana ketentuan dalam UndangUndang ini.

Berdasarkan penelitian di Komisi Pemilihan Umum Kota Kediri, kedua perintah pasal tersebut telah dijalankan dengan melakukan pelaksanaan pilkada secara langsung umum bebas dan rahasia. Di Kota Kediri ada 7 pasangan calon oleh partai politik dan dua pasangan calon dari perseorangan.

Penelitian ini bermaksud untuk mengetahui secara mendalam tentang dasar hukum dan mekanisme pendaftaran calon perseorangan dalam pemilihan umum Walikota dan Wakil Walikota di Kota Kediri. Persoalannya adalah apakah di Kota Kediri sudah melaksanakan prosedur mekanisme pendaftaran sesuai dengan peraturan yang berlaku. Di Kota Kediri sudah dua kali melakukan mekanisme pendafataran walikota tahun 2008 dan tahun 2013, berdasrkan pasal 58 hinggan pasal 64 UndangUndang Nomor 12 tahun 2008 


\section{Rumusan Masalah}

a. Apa dasar hukum pencalonan perseorangan dan partai politik dalam Pemilihan Umum Walikota dan Wakil Walikota di Kota Kediri tahun 2013.

b. Bagiamana Mekanisme Pencalonan Walikota dalam Undang-Undang Nomor 12 Tahun 2008 .

\section{Tujuan Penelitian}

a. Untuk mengkaji secara mendalam dasar hukum pencalonan perseorangan dan partai politik dalam Pemilihan Umum Walikota dan Wakil Walikota di Kota Kediri tahun 2013.

c. Untuk mengkaji secara mendalam Mekanisme Pencalonan Walikota dalam Undang-Undang Nomor 12 Tahun 2008

\section{B. PEMBAHASAN}

Dalam Pasal 58 Undang-Undang Nomor 12 Tahun 2008 berbunyi Calon kepala daerah dan wakil kepala daerah adalah warga negaraRepublik Indonesia yang memenuhi syarat :

1. Bertakwa kepada Tuhan Yang Maha Esa;

2. Setia kepada Pancasila sebagai Dasar Negara, Undang- Undang Dasar Negara Republik Indonesia Tahun 1945, cita-cita Proklamasi Kemerdekaan 17 Agustus 1945, dan kepada Negara Kesatuan Republik Indonesia serta Pemerintah;

3. Berpendidikan sekurang-kurangnya sekolah lanjutan tingkat atas dan/atau sederajat;

4. Berusia sekurang-kurangnya 30 (tiga puluh) tahun bagi calon gubernur/wakil gubernur dan berusia sekurang-kurangnya 25 (dua puluh lima) tahun bagi calon bupati/wakil bupati dan walikota/wakil walikota;

5. Sehat jasmani dan rohani berdasarkan hasil pemeriksaan kesehatan menyeluruh dari tim dokter; 
6. Tidak pernah dijatuhi pidana penjara berdasarkan putusan pengadilan yang telah memperoleh kekuatan hukum tetap karena melakukan tindak pidana yang diancam dengan pidana penjara 5 (lima) tahun atau lebih;

7. Tidak sedang dicabut hak pilihnya berdasarkan putusan pengadilan yang telah memperoleh kekuatan hukum tetap;

8. Mengenal daerahnya dan dikenal oleh masyarakat di daerahnya;

9. Menyerahkan daftar kekayaan pribadi dan bersedia untuk diumumkan;

10. Tidak sedang memiliki tanggungan utang secara perseorangan dan/atau secara badan hukum yang menjadi tanggung jawabnya yang merugikan keuangan negara;

11. Tidak sedang dinyatakan pailit berdasarkan putusan pengadilan yang telah memperoleh kekuatan hukum tetap;

12. Dihapus;

13. Memiliki Nomor Pokok Wajib Pajak (NPWP) atau bagi yang belum mempunyai NPWP wajib mempunyai bukti pembayaran pajak;

14. Menyerahkan daftar riwayat hidup lengkap yang memuat antara lain riwayat pendidikan dan pekerjaan serta keluarga kandung, suami atau istri;

15. Belum pernah menjabat sebagai kepala daerah atau wakil kepala daerah selama 2 (dua) kali masa jabatan dalam jabatan yang sama;

16. Tidak dalam status sebagai penjabat kepala daerah; dan

17. Mengundurkan diri sejak pendaftaran bagi kepala daerah dan/atau wakil kepala daerah yang masihmenduduki jabatannya. ${ }^{1}$

d. Berdasarkan penelitian di lapangan semua calon yang mendaftarkan diri sebagai bakal calon Walikota dan Wakil Walikota telah memenuhi syarat mulai dari point a hingga point $\mathrm{q}$ seperti yag

\footnotetext{
${ }^{1}$ Lihat Pasal 58 Undang-Undang Nomor 12 tahun 2008
} 
tercantum dalam pasal 58 Undang-Undang Nomor 12 tahun 2008.2

Sedangakan penerapan pasal 59 yang berbunyi 1. Peserta pemilihan

kepala daerah dan wakil kepala daerah adalah:

a. Pasangan calon yang diusulkan oleh partai politik atau gabungan partai politik.

b. Pasangan calon perseorangan yang didukung oleh sejumlah orang.

1) Partai politik atau gabungan partai politik sebagaimana dimaksud pada ayat (1) huruf a dapat mendaftarkan pasangan calon apabila memenuhi persyaratan perolehan sekurangkurangnya 15\% (lima belas persen) dari jumlah kursi DPRD atau $15 \%$ (lima belas persen) dari akumulasi perolehan suara sah dalam pemilihan umum anggota DPRD di daerah yang bersangkutan.

2) (2a). Pasangan calon perseorangan sebagaimana dimaksud pada ayat (1) huruf $b$ dapat mendaftarkan diri sebagai pasangan calon gubernur/wakil gubernur apabila memenuhi syarat dukungan dengan ketentuan:

1. Provinsi dengan jumlah penduduk sampai dengan 2.000.000 (dua juta) jiwa harus didukung sekurangkurangnya $6,5 \%$ (enam koma lima persen);

2. Provinsi dengan jumlah penduduk lebih dari 2.000.000 (dua juta) sampai dengan 6.000.000 (enam juta) jiwa harus didukung sekurang-kurangnya 5\% (lima persen);

3. Provinsi dengan jumlah penduduk lebih dari 6.000.000 (enam juta) sampai dengan 12.000.000 (dua belas juta) jiwa harus didukung sekurangkurangnya 4\% (empat persen); dan

\footnotetext{
${ }^{2}$ Hasil Observasi di KPU Kota Kediri
} 
4. Provinsi dengan jumlah penduduk lebih dari 12.000.000 (dua belas juta) jiwa harus didukung sekurang-kurangnya 3\% (tiga persen).

3) (2b) Pasangan calon perseorangan sebagaimana dimaksud pada ayat (1) huruf $b$ dapat mendaftarkan diri sebagai pasangan calon bupati/wakil bupati atau walikota/wakil walikota apabila memenuhi syarat dukungan dengan ketentuan:

1. Kabupaten/kota dengan jumlah penduduk sampai dengan 250.000 (dua ratus lima puluh ribu) jiwa harus didukung sekurang-kurangnya 6,5\% (enam koma lima persen);

2. Kabupaten/kota dengan jumlah penduduk lebih dari 250.000 (dua ratus lima puluh ribu) sampai dengan 500.000 (lima ratus ribu) jiwa harus didukung sekurang-kurangnya 5\% (lima persen);

3. Kabupaten/kota dengan jumlah penduduk lebih dari 500.000 (lima ratus ribu) sampai dengan 1.000.000 (satu juta) jiwa harus didukung sekurang-kurangnya $4 \%$ (empat persen); dan

4. Kabupaten/kota dengan jumlah penduduk lebih dari 1.000.000 (satu juta) jiwa harus didukung sekurangkurangnya 3\% (tiga persen).

4) (2c) Jumlah dukungan sebagaimana dimaksud dalam Pasal 59 ayat (2a) tersebar di lebih dari 50\% (lima puluh persen) jumlah kabupaten/kota di provinsi dimaksud.

5) (2d) Jumlah dukungan sebagaimana dimaksud dalam Pasal 59 ayat (2b) tersebar di lebih dari 50\% (lima puluh persen) jumlah kecamatan di kabupaten/kota dimaksud.

6) (2e) Dukungan sebagaimana dimaksud pada ayat (2a) dan ayat (2b) dibuat dalam bentuk surat dukungan yang disertai 
dengan fotokopi Kartu Tanda Penduduk (KTP) atau surat keterangan tanda penduduk sesuai dengan peraturan perundang-undangan.

7) (4a) Dalam proses penetapan pasangan calon perseorangan, KPU provinsi dan/atau KPU kabupaten/kota memperhatikan pendapat dan tanggapan masyarakat.

(1) Partai politik atau gabungan partai politik pada saat mendaftarkan calon partai politik, wajib menyerahkan :

1. Surat pencalonan yang ditandatangani oleh pimpinan partai politik atau pimpinan partai politik yang bergabung;

2. Kesepakatan tertulis antar partai politik yang bergabung untuk mencalonkan pasangan calon;

3. Surat pernyataan tidak akan menarik pencalonan atas pasangan yang dicalonkan yang ditandatangani oleh pimpinan partai politik atau para pimpinan partai politik yang bergabung.

4. Surat pernyataan kesediaan yang bersangkutan sebagai calon kepala daerah dan wakil kepala daerah secara berpasangan;

5. Surat pernyataan tidak akan mengundurkan diri sebagai pasangan calon.

6. Surat pernyataan kesanggupan mengundurkan diri dari jabatan apabila terpilih menjadi kepala daerah atau wakil kepala daerah sesuai dengan peraturan perundang-undangan.

7. Surat pernyataan mengundurkan diri dari jabatan negeri bagi calon yang berasal dari pegawainegeri sipil, anggota tentara nasional Indonesia, dan anggota kepolisian negara republik Indonesia; 
8. Surat pernyataan tidak aktif dari jabatannya bagi pimpinan dprd tempat yang bersangkutan menjadi calon di daerah yang menjadi wilayah kerjanya.

9. Surat pemberitahuan kepada pimpinan bagi anggota dpr, dpd, dan dprd yang mencalonkan diri sebagai calon kepala daerah dan wakil kepala daerah;

10. Kelengkapan persyaratan calon kepala daerah dan wakil kepala daerah sebagaimana dimaksud dalam pasal 58.

11. Visi, misi, dan program dari pasangan calon secara tertulis.

8) (4a) Dalam proses penetapan pasangan calon perseorangan, KPU provinsi dan/atau KPU kabupaten/kota memperhatikan pendapat dan tanggapan masyarakat.

9) (5a) Calon perseorangan pada saat mendaftar wajib menyerahkan:

1. Surat pencalonan yang ditandatangani oleh pasangan calon perseorangan.

2. Berkas dukungan dalam bentuk pernyataan dukungan yang dilampiri dengan fotokopi Kartu Tanda Penduduk atau surat keterangan tanda penduduk;

3. Surat pernyataan tidak akan mengundurkan diri sebagai pasangan calon;

4. Surat pernyataan kesanggupan mengundurkan diri dari jabatan apabila terpilih menjadi kepala daerah atau wakil kepala daerah sesuai dengan peraturan perundangundangan;

5. Surat pernyataan mengundurkan diri dari jabatan negeri bagi calon yang berasal dari pegawai negeri sipil, anggota Tentara Nasional Indonesia, dan anggota Kepolisian Negara Republik Indonesia; 
6. Surat pernyataan nonaktif dari jabatannya bagi pimpinan DPRD tempat yang bersangkutan menjadi calon kepala daerah dan wakil kepala daerah di daerah wilayah kerjanya;

7. Surat pemberitahuan kepada pimpinan bagi anggota DPR, DPD, dan DPRD yang mencalonkan diri sebagai calon kepala daerah dan wakil kepala daerah kelengkapan persyaratan calon kepala daerah dan wakil kepala daerah sebagaimana dimaksud dalam Pasal 58; dan

8. Visi, misi, dan program dari pasangan calon secara tertulis.

10) (5b) Dukungan sebagaimana dimaksud pada ayat (5a) huruf b hanya diberikan kepada satu pasangan calon perseorangan.

11)(6) Partai politik atau gabungan partai politik sebagaimana dimaksud pada ayat (2) hanya dapat mengusulkan satu pasangan calon dan pasangan calon tersebut tidak dapat diusulkan lagi oleh partai politik atau gabungan partai politik lainnya.

12) (7) Masa pendaftaran pasangan calon sebagaimana dimaksud pada ayat (1) paling lama 7 (tujuh) hari terhitung sejak pengumuman pendaftaran pasangan calon. ${ }^{3}$

Di antara Pasal 59 dan Pasal 60 disisipkan 1 (satu) pasal, yakni Pasal 59A, yang berbunyi sebagai berikut:

1. Verifikasi dan rekapitulasi dukungan calon perseorangan untuk pemilihan gubernur/wakil gubernur dilakukan oleh KPU provinsi yang dibantu oleh KPU kabupaten/kota, PPK, dan PPS.

2. Verifikasi dan rekapitulasi dukungan calon perseorangan untuk pemilihan bupati/wakil bupati dan walikota/wakil walikota

\footnotetext{
${ }^{3}$ Lihat Pasal 59 Undang-undang Nomor 12 Tahun 2008
} 
dilakukan oleh KPU kabupaten/kota yang dibantu oleh PPK dan PPS.

3. Bakal pasangan calon perseorangan untuk pemilihan bupati/wakil bupati dan walikota/wakil walikota menyerahkan daftar dukungan kepada PPS untuk dilakukan verifikasi paling lambat 21 (dua puluh satu) hari sebelum waktu pendaftaran pasangan calon dimulai.

4. Bakal pasangan calon perseorangan untuk pemilihan gubernur/wakil gubernur menyerahkan daftar dukungan kepada PPS untuk dilakukan verifikasi paling lambat 28 (dua puluh delapan) hari sebelum waktu pendaftaran pasangan calon dimulai.

5. Verifikasi sebagaimana dimaksud pada ayat (3) dan ayat (4) dilakukan paling lama 14 (empat belas) hari sejak dokumen dukungan bakal pasangan calon perseorangan diserahkan.

6. Hasil verifikasi dukungan calon perseorangan sebagaimana dimaksud pada ayat (5) dituangkan dalam berita acara, yang selanjutnya diteruskan kepada PPK dan salinan hasil verifikasi disampaikan kepada bakal pasangan calon.

7. PPK melakukan verifikasi dan rekapitulasi jumlah dukungan bakal pasangan calon untuk menghindari adanya seseorang yang memberikan dukungan kepada lebih dari satu bakal pasangan calon dan adanya informasi manipulasi dukungan yang dilaksanakan paling lama 7 (tujuh) hari.

8. Hasil verifikasi dan rekapitulasi dukungan calon perseorangan sebagaimana dimaksud pada ayat (6) dituangkan dalam berita acara yang selanjutnya diteruskan kepada KPU kabupaten/kota dan salinan hasil verifikasi dan rekapitulasi disampaikan kepada bakal pasangan calon.

9. Dalam pemilihan bupati/wakil bupati dan walikota/wakil walikota, salinan hasil verifikasi dan rekapitulasi sebagaimana dimaksud pada ayat (8) dipergunakan oleh bakal pasangan calon dari 
perseorangan sebagai bukti pemenuhan persyaratan dukungan pencalonan.

10. KPU kabupaten/kota melakukan verifikasi dan rekapitulasi jumlah dukungan bakal pasangan calon untuk menghindari adanya seseorang yang memberikan dukungan kepada lebih dari satu bakal pasangan calon dan adanya informasi manipulasi dukungan yang dilaksanakan paling lama 7 (tujuh) hari.

11. Hasil verifikasi dan rekapitulasi dukungan calon perseorangan sebagaimana dimaksud pada ayat (10) dituangkan dalam berita acara yang selanjutnya diteruskan kepada KPU provinsi dan salinan hasil verifikasi dan rekapitulasi disampaikan kepada bakal pasangan calon untuk dipergunakan sebagai bukti pemenuhan persyaratan jumlah dukungan untuk pencalonan pemilihan gubernur/wakil gubernur. ${ }^{4}$

Ketentuan Pasal 60 bahwa pasangan calon sebagaimana dimaksud dalam Pasal 59 ayat (1) diteliti persyaratan administrasinya dengan melakukan klarifikasi kepada instansi pemerintah yang berwenang dan menerima masukan dari masyarakat terhadap persyaratan pasangan calon.

Berdasarkan pasal tersebut, maka petugas KPU Kota Kediri mendatangi intansi atau lembaga yang terkait dengan bakal calon walikota perseorangn maupun dari partai politik dan gabungan partai politik. Hasil penelitian pada ayat (1) tersebut diberitahukan secara tertulis kepada calon partai politik dengan tembusan pimpinan partai politik, gabungan partai politik yang mengusulkan, atau calon perseorangan paling lama 21 (dua puluh satu) hari terhitung sejak tanggal penutupan pendaftaran. ${ }^{5}$

(1) Apabila pasangan calon partai politik atau gabungan partai politik belum memenuhi syarat atau ditolak karena tidak memenuhi syarat sebagaimana dimaksud dalam Pasal 58 dan/atau Pasal 59 ayat (5), partai politik atau gabungan partai politik yang mengajukan calon

\footnotetext{
${ }^{4}$ Lihat Pasal 59A Undang-Undang Nomor 12 Tahun 2008

${ }^{5}$ Wawancara dengan Komisioner KPU Kota Kediri, Tanggal 17 April 2014
} 
diberi kesempatan untuk melengkapi dan/atau memperbaiki surat pencalonan beserta persyaratan pasangan calon atau mengajukan calon baru paling lama 7 (tujuh) hari sejak saat pemberitahuan hasil penelitian persyaratan oleh KPU provinsi dan/atau KPU Kabupaten/Kota.

(3a) Apabila belum memenuhi syarat sebagaimana dimaksud dalam Pasal 58 dan Pasal 59 ayat (5a) huruf b, huruf c, huruf d, huruf e, huruf $f$, huruf g, huruf $h$, dan huruf $i$, calon perseorangan diberi kesempatan untuk melengkapi dan/atau memperbaiki surat pencalonan beserta persyaratan pasangan calon paling lama 7 (tujuh) hari sejak saat pemberitahuan hasil penelitian persyaratan oleh KPU provinsi dan/atau KPU Kabupaten/Kota.

(3b) Apabila belum memenuhi syarat sebagaimana dimaksud dalam Pasal 59 ayat (5a) huruf a, calon perseorangan diberi kesempatan untuk melengkapi dan/atau memperbaiki surat pencalonan beserta persyaratan pasangan calon paling lama 14 (empat belas) hari sejak saat pemberitahuan hasil penelitian persyaratan oleh KPU Provinsi dan/atau KPU Kabupaten/Kota.

(3c) Apabila calon perseorangan ditolak oleh KPU Provinsi dan/atau KPU Kabupaten/Kota karena tidak memenuhi persyaratan sebagaimana dimaksud dalam Pasal 58 atau Pasal 59 ayat (5a), pasangan calon tidak dapat mencalonkan kembali.

1. KPU Provinsi dan/atau KPU Kabupaten/Kota melakukan penelitian ulang tentang kelengkapan dan/atau perbaikan persyaratan calon sebagaimana dimaksud pada ayat (3), ayat (3a), dan ayat (3b) sekaligus memberitahukan hasil penelitian tersebut paling lama 14 (empat belas) hari kepada pimpinan partai politik atau gabungan partai politik yang mengusulkannya atau calon perseorangan.

2. Apabila hasil penelitian berkas calon sebagaimana dimaksud pada ayat (4) tidak memenuhi syarat dan ditolak oleh KPU 
Provinsi dan/atau KPU Kabupaten/Kota, partai politik, gabungan partai politik, atau calon perseorangan tidak dapat lagi mengajukan calon.

3. Ketentuan lebih lanjut mengenai tata cara penelitian persyaratan administrasi pasangan calon sebagaimana dimaksud pada ayat (1) diatur dengan peraturan KPU.

KPU Kota Kediri, berdasarkan UU 12 tahun 2008 mulai pasal 58 hingga 60, telah melaksanakan dengan sungguh sungguh hasilnya semua calon baik perseorangn maupun dari partai politik dan gabungan partai politik lolos dalam tahapan pendaftaran. ${ }^{6}$

Dalam mekanisme pencalonan Walikota di Kediri, selain berdasarkan UU 12 tahun 2008 KPU juga mendasarkan diri pada :

1. Peraturan Komisi Pemilihan Umum Nomor 13 tahun 2010 yang telah diubah dengan Peraturan Komisi Pemilihan Umum Nomor 9 Tahun 2012 Tentang Pedoman Teknis Pencalonan Pemilihan Umum Kepala Daerah dan Wakil Kepala Daerah.

2. Surat Keputusan Komisi Pemilihan Umum Kota Kediri Nomor : 01/Kpts/KPUKota-014.329976/2013 Tentang Tahapan, Program dan Jadwal Penyelenggara Pemilihan Umum Walikota dan Wakil Walikota Tahun 2013.

3. Surat Keputusan Komisi Pemilihan Umum Kota Kediri Nomor: 07/Kpts/KPUKota-014.329976/2013 Tentang Pedoman Teknis Pencalonan Pemilihan Umum Walikota dan Wakil Walikota Tahun 2013.

Sistem pencalonan pilkada langsung yang dirumuskan dalam Undangundang Nomor 32 Tahun 2004 dan Peraturan Pemerintah Nomor 6 Tahun 2005 merupakan sistem yang tidak memiliki batas-batas yang tegas sebagai system terbatas atau terbuka. Indikator utama bahwa batas sistem pencalonan tidak jelas adalah bahwa mekanisme pendaftaran calon menempatkan partai

\footnotetext{
${ }^{6}$ Hasil Observasi di KPU Kota Kediri
} 
politik pada posisi dan fungsi yang sangat strategis atau menentukan ${ }^{7}$, namun calon perseorangan diakomodir dalamn proses pencalonan pilkada langsung tetapi aksesnya sangat sempit.

Sempitnya akses calon perseorangan itulah yang memberi konfirmasi bahwa nuansa rekrutmen calon oleh partai menggunakan sistem tertutup. ${ }^{8}$ Peserta dalam pemilihan kepala daerah dan wakil kepala daerah adalah pasangan calon yang diusulkan secara berpasangan oleh partai politik atau gabungan partai politik. Pengertian partai politik atau gabungan partai politik dalam hal ini, adalah partai politik atau gabungan partai politik yang memiliki kursi di Dewan Perwakilan Rakyat Daerah. Dengan ditetapkannya keputusan Mahkamah.

Konstitusi Nomor 005/PUU-III/2005, berkenaan dengan permohonan uji materil terhadap penjelasan pasal 59 ayat (1) Undang-undang Nomor 32 Tahun 2004 tentang Pemerintahan Daerah, maka MK dalam putusannya menyatakan $:^{9}$

1. Penjelasan pasal 59 ayat (1) Undang-undang Nomor 32 Tahun 2004 tentang Pemerintah Daerah bertentangan dengan UUD RI Tahun 1945.

2. Penjelasan pasal 59 ayat (1) Undang-undang Nomor 32 Tahun 2004 tentang Pemerintah Daerah tidak mempunyai kekuatan hukum mengikat.

Dengan adanya putusan Mahkamah Konstitusi ini, partai politik atau gabungan partai politik peserta pemilu 2004 yang tidak memiliki kursi di Dewan Perwakilan Rakyat Daerah, dapat mengusulkan pasangan calon kepala daerah dan wakil kepala daerah dalam pilkada, asal saja partai politik atau gabungan partai politik dimaksud memiliki akumulasi suara sah pada pemilu legislatif yang lalu, sekurang-kurangnya $15 \%$.

\footnotetext{
${ }^{7}$ Lihat pasal 59 ayat (1) Undang-Undang Nomor 32 Tahun 2004.

${ }^{8}$ Lihat pasal 59 ayat (3) Undang-Undang Nomor 32 Tahun 2004

${ }^{9}$ Joko P. Prihatmoko, Men Demokrasi kan Pemilu dari Sistem sampai Elemen Teknis, kerjasama LP3M UNWAHAS, dan Pustaka Pelajar, Semarang, 2007, hal. 240-241
} 
Sesuai dengan tahapan pencalonan yang tertuang dalam SK KPU Kota Kediri Nomor: 07/Kpts/KPUKota-014.329976/2013, Tentang Pedoman Teknis Pencalonan Pemilihan Umum Walikota dan Wakil Walikota Kediri Tahun 2013, tahapan pencalonan dimulai dengan koordinasi dengan partai politik, sosialisasi tata cara yang melibatkan semua pihak yang berkepentingan dengan pencalonan dan koordinasi dengan lembaga persyaratan pencalonan. Rapat koordinasi tidak hanya dilakukan sekali akan tetapi berkali-kali untuk menyamakan persepsi. ${ }^{10}$

Setelah koordinasi dengan lembaga terkait, langkah KPU Kota Kediri melakukan koordinasi internal dalam rangka pembagian tugas untuk megefektifkan kegiatan pencalonan, dengan menyusun kegiatan sebagaimana tabel sebagai berikut :

Tabel 1. Program Jadwal Waktu Pencalonan

\begin{tabular}{|c|c|c|c|}
\hline \multirow{2}{*}{$\begin{array}{l}\text { TAHAPAN/PROGRAM/ } \\
\text { JADWAL WAKTU }\end{array}$} & \multicolumn{2}{|c|}{ KEGIATAN } & \multirow{2}{*}{ KET } \\
\hline & MULAI & SELESAI & \\
\hline $\begin{array}{l}\text { Pengumuman, } \\
\text { penyerahan dan } \\
\text { kesempatan memperbaiki } \\
\text { dokumen dukungan } \\
\text { perseorangan }\end{array}$ & 7 April 2013 & 11 April 2013 & \\
\hline $\begin{array}{l}\text { Verifikasi dan } \\
\text { rekapitulasi berkas } \\
\text { dukungan calon } \\
\text { perseorangan }\end{array}$ & 15 April 2013 & 12 Mei 2013 & \\
\hline $\begin{array}{l}\text { Pendaftaran Pasangan } \\
\text { calon yang diajukan oleh } \\
\text { Parpol/ Gabungan Parpol } \\
\text { dan Perseorangan }\end{array}$ & 13 Mei 2013 & 19 Mei 2013 & \\
\hline $\begin{array}{l}\text { Perbaikan/ melengkapi } \\
\text { kekurangan berkas } \\
\text { persyaratan pencalonan }\end{array}$ & 10 Juni 2013 & 23 juni 2013 & \\
\hline
\end{tabular}

${ }^{10}$ Dokumentasi Kantor KPU Kota Kediri 


\begin{tabular}{|l|l|l|l|}
\hline $\begin{array}{l}\text { Penelitian ulang terhadap } \\
\text { berkas persyaratan }\end{array}$ & 24 Juni 2013 & 7 Juli 2013 & \\
\hline $\begin{array}{l}\text { Pencalonan Penyampaian } \\
\text { Hasil Pemeriksaan } \\
\text { Kesehatan }\end{array}$ & 16 Mei 2013 & 23 Juni 2013 & \\
\hline $\begin{array}{l}\text { Pengumuman pasangan } \\
\text { calon yang memenuhi } \\
\text { persyaratan }\end{array}$ & 8 Juli 2013 & 14 Juli 2013 & \\
\hline $\begin{array}{l}\text { Penentuan dan penetapan } \\
\text { nomor urut }\end{array}$ & 14 Juli 2013 & 15 Juli 2013 & \\
\hline $\begin{array}{l}\text { Pengumuman penetapan } \\
\text { nomor urut }\end{array}$ & 15 Juli 2013 & 21 Juli 2013 & \\
\hline $\begin{array}{l}\text { Deklarasi pemilukada } \\
\text { damai }\end{array}$ & 11 Agustus 2013 & 11 Agustus 2013 & \\
\hline Debat Publik & 24 Agustus 2013 & 24 Agustus 2013 & \\
\hline
\end{tabular}




\section{PENUTUP}

\section{Kesimpulan}

a. Pemilihan Umum Walikota di Kediri untuk mekanisme pencalonan calon perseorangan dan partai politik menggunakan dasar UndangUndang Nomor: 12 Tahun 2008 mulai pasal 58 hingga 60. Selain juga menggunan Undang-Undang 32 Tahun 2004.

b. Di Kota Kediri telah melaksanakan mekanisme pendaftaran calon Walikota dan Wakil Walikota berasal dari Parpol, gabungan Parpol dan calon Perseorangan dengan sungguh-sungguh hasilnya semua calon baik perseorangn maupun dari partai politik dan gabungan partai politik lolos dalam tahapan pendaftaran. Partai politik atau gabungan partai politik yang dapat mengusulkan pasangan calon adalah partai politik atau gabungan partai politik yang memenuhi syarat: Pertama memiliki sekurang-kurangnya lima belas persen kursi di Dewan Perwakilan Rakyat Daerah. Kedua memiliki lima belas persen akumulasi perolehan suara sah dalam daerah pemilihan yang bersangkutan. 


\section{DAFTAR PUSTAKA}

Undang-Undang Nomor 32 Tahun 2004 tentang

Undang-Undang Nomor 12 Tahun 2008 tentang

Joko P. Prihatmoko, Men Demokrasikan Pemilu dari Sistem sampai Elemen Teknis, kerjasama LP3M UNWAHAS, dan Pustaka Pelajar, Semarang, 2007.

Rozali Abdullah, Pelaksanaan Otonomi Luas dengan Pemilihan Kepala Daerah Secara Langsung, PT. RajaGrafindo Persada, Jakarta, 2005.

Dokumentasi Kantor KPU Kota Kediri

Hasil Observasi di KPU Kota Kediri

Wawancara dengan Komisioner KPU Kota Kediri. 